\title{
Self-Protective Safety Devices: An Economic Analysis
}

Because of recent technological advances, it is possible for potential victims of certain kinds of accidents to take precautions that, while not able to prevent accidents, can reduce the extent of loss if accidents occur. The event of primary significance in tort law, however, has always been the act or omission that harmed the victim. The full costs of the accident have traditionally been assessed against the party who "causes" the harm. Although there is an obligation to minimize injuries after the tort has occurred, ${ }^{1}$ there are no doctrines that expressly treat preaccident injury-preventive measures. Courts have, therefore, been reluctant to require self-protective precautions, ${ }^{2}$ perhaps because until recently few opportunities for this form of injury prevention have been available. ${ }^{3}$ Such precautions have been required only in industrial contexts, in which the employee can easily foresee the savings made possible by safety precautions, ${ }^{4}$ and in certain highly unusual situations. ${ }^{6}$ Most courts have overlooked the underlying consistency between injury-preventive and accident-preventive precautions, and between the safety obligations of "injurers" and "victims." 6

The traditional function of tort litigation is to settle private disputes

1 E.g., City of Duncan v. Nicholson, 118 Okla. 275, 247 P. 979 (1926).

2 As a result of technological advances, large segments of the public can greatly reduce the losses from accidental injuries by using "self-protective" safety devices, for example, motorcycle helmets, seat belts, goggles, safety shoes, and life preservers. The analysis also embraces self-protective safety precautions that involve no device. See, e.g., Harris v. Toronto Transit Comm'n, 1967 S.C.R. 460.

Self-protective precautions have been required in automotive safety legislation. These devices do not, however, directly present the issue of liability for nonuse because the installation of these features makes nonuse impossible. E.g., 49 G.F.R. $\$ 571.207$ (1972) (passenger seat construction requirements specifying minimum resistance to impact). That the duty to install such devices rests on the manufacturer is immaterial. The result of the requirement is that consumers must purchase devices that inure to their benefit only. In contrast to obligations involving physical participation by the party to be protected, self-protective obligations to make expenditures have raised no noticeable controversy.

3 The obligation to minimize damages has traditionally applied only to postaccident conduct, W. Prosser, LAW of Torts $\S 65$, at 422-23 (4th ed. 1971), such as failure to seek medical treatment, e.g., Moulton v. Alamo Ambulance Serv., Inc., 414 S.W.2d 444 (Tex. 1967); Kircher, Miller v. Miller: The Safety Belt Defense, 35 INs. Counser J. 432, 438 (1968).

4 E.g., Nashville, G. \& St. L. Ry. v. Coleman, 151 Tenn. 443, 269 S.W. 919 (1924); Kirk v. United States, 161 F. Supp. 722 (S.D. Idaho 1958).

5 E.g., Wright v. Illinois \& Miss. Tel. Co., 20 Iowa 195 (1866).

B See, e.g., Miller v. Miller, 273 N.C. 228, 160 S.E.2d 65 (1968). 
over compensation. The courts' post facto perspective on accidents often results in insufficient attention to the costs allocated by liability rules and their impact on the behavior of parties who may never be in court. ${ }^{7}$ Because of emphasis on dispute settlement, courts have often neglected to consider, in light of all the variables in an accident situation, what liability rule would minimize the total costs of the conflicting activities involved. The appropriate liability rule can be determined by viewing the parties to accident litigation in their economic relationships ${ }^{8}-$ not as plaintiffs and defendants or victims and injurers, but as participants in cost-inflicting activities that must be reconciled by the law. ${ }^{9}$ The appropriate unit for analysis includes not only "the accident" but the continuous series of harms within each accident, some of which can be avoided most cheaply by one party, and others by another party. ${ }^{10}$

This comment discusses the legal and economic consequences of nonuse of self-protective devices. The analysis develops a theoretical framework for considering such devices, examines, in the context of that framework, the use of one device-an available automotive seat belt-and proposes a change in the liability rule for seat belt nonuse.

\section{The Theoreticat Framework}

\section{A. The Standard Negligence Model}

1. Economic Concepts. Economic analysis of self-protective safety measures is similar to the analysis of negligence generally; it uses three basic concepts: cost, efficiency, and transaction cost. ${ }^{11}$

7 See, e.g., Dillon v. Fumphries, 56 Misc. 2d 211, 215, 288 N.X.S.2d 14, 19 (Sup. C.t. 1968) ("Use of seat belts should be encouraged, but not at the sacrifice of existing case law.")

8 It has been suggested that there is an implicit economic logic to common law tort cases. Posner, $A$ Theory of Negligence, 1 J. LeGal Studres 29 (1972). As the author notes, however, this inarticulate economic intuition cannot always be relied upon to minimize costs. Id. at 74 .

9 As Professor Coase has observed, the problem of reconciling conflicting activities is a reciprocal one. Coase, The Problem of Social Cost, 3 J. LAw \& Econ. 1, 2 (1960).

10 The concept of an accident as increments of harm is implied, for example, in the phrase "the second accident," which is used to describe the impact of vehicle occupants against the automobile interior. E.g., Walker \& Beck, Seat Belts and the Second Accident, 34 INs. CounseL J. 349 (1967).

Where one accident occurs, and then the victim causes another harm after a brief interval, the courts have no trouble separating liability for the two events. See, e.g., Owens v. Simon, $245 \mathrm{Md}$. 404, 226 A.2d 548 (1967). But the principle is apparently lost when the two accidents are separated by only an instant.

11 This section is based on Coase, supra note 9, and its progeny, e.g., G. STIGLER, A THEORY of PRICE 110-20 (3d ed. 1966); Calabresi \& Melamed, Property Rules, Liability Rules and Inalienability: One View of the Cathedral, 85 HARv. L. REv. 1089 (1972); Demsetz, When Does the Rule of Liability Matter? I J. Legal Studies 13 (1972); Posner, supra note 8. 
a. Cost. The cost of any product or activity is the market-determined value or price that the resources necessary for the product or activity would bring if they were used for some other end. When there are alternatives, there are costs. ${ }^{12}$

b. Efficiency. Efficiency is increased by a transaction that operates to the advantage of both parties. ${ }^{13}$ Efficiency-increasing transactions replace less valuable activities or products with more valuable ones. The following hypothetical case illustrates such a transaction. Railroad tracks abut a farmer's hay field. Sparks from the trains cause fires that annually destroy $\$ 1,000$ worth of hay, and there is no legal remedy for the loss. The railroad can install a spark arrester that would cost $\$ 100$ per year for installation and maintenance, and that would reduce fire losses to $\$ 500$ per year. If the farmer pays the railroad $\$ 150$ to install the device, both parties' positions will be improved. The railroad will be $\$ 50$ richer, and the farmer's total losses will be $\$ 350$ less. ${ }^{14}$

c. Transaction Costs. The cost of arranging efficiency-increasing transactions is important. If, for example, the farmer's cost for the spark arrester plus his cost in arranging an agreement with the railroad exceeds the $\$ 500$ gain from the reduction in fire loss, he will permit the fire losses to continue.

If transactions are costless, parties will, as in the railroad case, arrange all cost-justifiable accident precautions among themselves. ${ }^{15}$ Where transaction costs are prohibitive, however, liability rules approximate the effect of an efficiency-increasing transaction by allocating costs in accordance with the negligence formula announced by Judge Learned Hand in United States v. Carroll Towing Co. ${ }^{18}$ This formula requires prevention of an accident whenever the burden of prevention is less than the probability of occurrence multiplied by the size of the loss. The formula must be applied to all the parties to the accident, so that the party with the smallest burden of prevention will be required to act. In the railroad case, assuming that the farmer can prevent the fire loss at a cost of $\$ 125$, and that the railroad can prevent it at a cost

12 A. Alchian \& W. Allen, Exchange and Production: Theory in Use 39-43 (1969); Coase, The Nature of Costs, in Studies in Cost ANAlysis 118 (D. Solomons ed. 1968).

13 Coase, supra note 12 , at 118.

14 This hypothetical situation has a distinguished history in economic literature. See A. Pigou, The Economics of Welfare 129-30 (4th ed. 1932); Coase, supra note 9, at 29-84; Posner, supra note 8 at 60; Posner, Strict Liability: A Comment, 2 J. LEGAL STUdies 205, 205-07 (1973). The situation is also amenable to property law treatment, but the formal boundaries between property and tort law are not important for this analysis, Calabresi \& Melamed, supra note 11, at 1089.

15 Coase, supra note 9 , at 15 . Of course, if the cost of prevention is greater than the accident cost for all the parties, prevention will not occur, even if transaction costs are zero. 10159 F.2d 169 (2d Cir. 1947). 
of $\$ 100$, if transaction costs are more than $\$ 25$, imposing liability on the farmer wastes $\$ 25$. Assigning the obligation to the railroad conforms the parties' behavior to the result of the efficiency-increasing transaction.

Even if transaction costs are small, the duty of prevention should be assigned to the party who can prevent the harm for the lower cost. If the transaction cost in the railroad case is $\$ 10$, assigning the duty to the farmer will not obstruct an efficiency-increasing transaction. The farmer, facing a $\$ 125$ prevention cost, will pay the railroad to take the $\$ 100$ precaution. But, if the railroad is held liable, the transaction cost of $\$ 10$ will be avoided.

2. Distribution of Income. The analysis thus far has proceeded on the assumption that liability rules should be designed to duplicate the results of efficiency-increasing transactions. Liability rules affect the relative wealth of parties. There are, however, several reasons for ignoring these income-distributional considerations. First, there is no evidence that the net effect of a society's liability rules gives any income advantage to a particular group..$^{17}$ Second, even if it could be determined that some groups receive net benefits from liability rules, there would be no rational method to determine whether that distribution of income is socially desirable;18 nor can a distributional "gain" be weighed against a reduction in efficiency. If, for instance, the farmer is able to move his hay at a cost of $\$ 75, \$ 25$ less than the cost of the spark arrester, he should be required to take that precaution. If the railroad were found liable in order to avoid a wealth loss to farmers, there would be no way to measure this benefit against the $\$ 25$ loss in efficiency. Finally, even if the disadvantaged groups were clearly identifiable and there

17 The incidence of costs is often very difficult to determine. See, e.g., Goode, The Postwar Corporate Tax Structure, in FEDERAL InCOME, ESTATE, AND GIFT TAXATION (B. Bittker ed. 1958). In many accident situations, consumers may ultimately bear the prevention costs irrespective of which party is assigned the obligation. Moreover, the injurer and victim groups often substantially overlap.

18 "Loss-shifting"--holding defendants liable for harms suffered by plaintiffs-is often defended on distributional grounds. Thus one writer invokes "the desire to compensate injured persons and effect a wide and efficient distribution of accident losses." Kleist, The Seat Belt Defense-An Exercise in Sophistry, 18 HAstings L.J. 613, 616 (1967). To decide whether loss-shifting distributes costs more widely it would be necessary to ascertain the size and composition of the plaintiff and defendant groups. In addition, it cannot be assumed that defendants are more able to bear accident costs than plaintiffs. There is no reason to believe that defendants have a higher average income than plaintiffs. But even if plaintiffs as a class are poorer than defendants, it is impossible to determine whether they value the accident cost more than defendants. The value a richer man places on his $n$th dollar cannot be compared with the value a poorer man places on his $m$ th dollar. $H$. Simons, Personal Income Taxation 5-11 (1938). 
were a positive case for adjusting the distribution of income to their benefit, a liability rule would be an inefficient way to accomplish the redistribution. ${ }^{19}$

\section{B. The Self-Protective Safety Variation}

Self-protective safety precautions can be analyzed using the negligence model with minor variations. Two categories of precautions must be considered: those that reduce the harm from an accident they cannot prevent-for example, the use of seat belts and motorcycle helmets-and those accident-preventive precautions that are considered self-protective because all the harm ordinarily falls on the potential user of the device. Use by a pedestrian of a brightly colored jacket after dark falls into the latter category since it may enable him to avoid being struck by a vehicle. ${ }^{20}$

1. Increments of Harm. Although in most negligence cases "the accident" is treated as an indivisible unit of harm, in many instances the harm can be divided into increments. When these increments can be isolated, the negligence formula should be applied to each increment rather than to the accident as a whole. In the railroad example, $\$ 500$ of fire loss was eliminated by the use of a $\$ 100$ spark arrester. Assume that fire damage can be reduced by an additional $\$ 400$ by extending at a cost of $\$ 100$ a pipeline from the farmer's well to the area near the railroad tracks. The pipeline cannot prevent the accident, but if the accident occurs, the pipeline will enable the farmer to extinguish the fire more quickly and thus mitigate the damages. If the railroad is held liable for the damage the pipeline could prevent, the railroad will pay the farmer to install the system. Accordingly, the duty to take that precaution should be assigned in the first instance to the farmer, in order to avoid an unnecessary, and perhaps prohibitively expensive, transaction. Thus, if the farmer sues the railroad for the fire damage, his recovery should be reduced by the amount of the loss he could have prevented by installing the pipeline; ${ }^{21}$ but the railroad should still be liable for that

$10 \mathrm{H}$. Sumons, supra note 18 , at $38-40$. When liability rules are used for redistribution of income, they are similar to excise taxes. Although redistribution through the personal income tax also has adverse substitution effects, it is a more accurate device for redistribution.

20 Economically, there is no need to distinguish these two groups of precautions because the same reasoning applies whether the precaution prevents all or only part of the harm. Doctrinally, however, there is a difference. The first group falls under a mitigation-ofdamages heading; the second group presents the standard contributory negligence case.

21 In this situation, imposing the obligation on the farmer to install the pipeline would not affect the railroad's incentive to install the spark arrester, because the losses the pipe- 
portion of the loss that could have been avoided by use of a spark arrester.

2. Foreseeability. The duty to take self-protective precautions may require that one party foresee the negligence of the other. Such a requirement is disfavored by traditional tort analysis, in part because of concern that a duty to foresee another's negligence and take appropriate action would be difficult to circumscribe..$^{22}$ As one court recently stated: "[T]he courts are aware that other protective devices and measures are undergoing testing in governmental and private laboratories, or are on the drawing boards. The concern is, of course, that if the seat belt defense is allowed, would not the same analysis require the use of all safety devices with which one's auto is equipped."23

Foresight and floodgates problems do not arise, however, if the appropriate costs are weighed. The cost of preventing a loss embraces the cost of taking a precaution on the occasions when no accident occurs as well as when one does. Assume that the farmer can reduce fire losses from $\$ 1,000$ to $\$ 100$ annually by stationing a farmhand near the tracks at a cost of $\$ 100$ per month. If the farmer can predict in which month the fire loss will occur, he can save $\$ 900$ worth of crops by taking a $\$ 100$ precaution, even though the farmhand's presence will not prevent "the accident." But if, as is likely, no such prediction can be made, the farmer will find it necessary to use a farmhand as a fireman throughout the year, thus expending $\$ 1,200$ to prevent a $\$ 900$ loss. It is both predictable and desirable that technological change give rise to new precautionary obligations. The law should not, however, impose duties of self-protection that are not cost-justified, since the potential victim would permit the loss to occur in spite of the obligation imposed. ${ }^{24}$

line reduces are, by hypothesis, unpreventable by the railroad. Imposing the self-protective safety obligation is more problematic if the initial injurers are not taking all cost-justified measures, or if the self-protective precaution would also eliminate part of the loss prevented by the injurer group's precautions. This problem complicates the question whether automobile occupants should be obligated to use available seat belts. See text and notes at notes $41-44$ infra.

22 E.g., Kleist, supra note 18, at 621-22.

23 Derheim v. N. Fiorito Co., 80 Wash. 2d 161, -, 492 P.2d 1030, 1035 (1972).

24 The Carroll Towing formula takes into account the costs of foresight by discounting the size of the loss in a given accident by the probability of its occurrence. The same result is reached by multiplying the cost of prevention in the accident itself by the number of times the precaution must be taken for prevention to be effective. The cost of prevention also includes the cost of determining the probability of occurrence. That cost declines as experience with a particular type of accident increases and becomes widely known. 


\section{Nonuse of an Available Seat Belt}

Recently the courts have been called upon to decide the self-protective safety issue in the context of available automotive seat belts. ${ }^{25}$ While most courts have held that there is no obligation to use the device, ${ }^{26}$ analysis of the costs of seat belt use and nonuse indicates that the imposition of liability for nonuse of available seat belts would in all likelihood reduce accident losses.

\section{A. Cost of Nonuse}

Evaluation of a change in the liability rule for seat belt nonuse requires, in accordance with the foregoing conceptual analysis, the division of automobile accidents into segments of harm. The critical segment of harm for this evaluation comprises losses that result from nonuse of available seat belts. These losses, however, are not easily measured. Accident loss statistics are approximate at best, and calculations of the loss-preventive potential of the device differ significantly. ${ }^{27}$ Statistics of the National Safety Council suggest that, in 1971, direct losses, such as medical expenses and lost wages, due to nonuse of seat belts can be conservatively estimated at one billion dollars. ${ }^{28}$ This

25 The availability qualification is important because the costs of using available seat belts are less than the costs of universal seat belt use. The costs of universal seat belt use include the expense of installing the device in all types of vehicles. For some classes of vehicles, such as school buses, this would require expensive redesigning. 37 Fed. Reg. 9213 (1972).

As used in this section the term "automobile occupants" embraces drivers as well as passengers because drivers are both potential "injurers" and potential "victims," and thus are able to take both injury-preventive and accident-preventive precautions.

28 See notes 59-64 infra.

27 That the device measurably reduces injuries is beyond doubt. See Bowman, Proving the Seat Belt Defense, 37 Ins. Counser J. 385 n.1, 386 n.8 (1970); Huelke, Practical Defense Problems and The Expert's View, 53 MArQ. L. Rev. 203 (1970); Miller, The Crashworthiness of Automobiles, ScIENTIFic Am. Feb., 1973, at 81; Snyder, The Seat Belt as a Cause of Injury, 53 Mare. L. Rev. 211 and studies cited at nn.l-5 (1970). Despite overwhelming evidence, many legal commentators continue to treat the effectiveness of seat belts as purely speculative. E.g., Comment, The Emerging Seat Belt Defense: Two Views, 5 AKroN L. REv. 129, 138 (1972).

28 Costs reducible through use of available seat belts for 1971 can be derived from the following calculation. Direct personal injury losses from motor vehicle accidents (including medical expenses, wage loss, and insurance administration cost) were $\$ 10.8$ billion, National Safety Councir, Accident Facts 5 (1972). Insurance administration costs were $\$ 6.0$ billion. Id. at 5 . Although this item might be reduced somewhat by use of seat belts, the amount of the reduction cannot be estimated and is omitted to ensure a conservative estimate. The difference between these two figures, $\$ 4.8$ billion, equals the total direct losses upon which seat belt use could have had an effect in 1971. The current extent of use of available seat belts, 33 per cent, $i d$. at 53 , multiplied by the loss-preventive potential of seat belts, 33 percent, Huelke, supra note 27, at 203, yields 11 percent, the percentage of losses 
figure does not include several significant loss items that are extremely difficult to measure: costs of pain and suffering to the victim ${ }^{20}$ and indirect losses to employers, consumers, and investors..$^{30}$ Thus, although the total cost of nonuse of available seat belts cannot be precisely determined, the figure is very likely in the billions of dollars. ${ }^{31}$ The inquiry

that would have occurred in 1971 if no seat belts had been worn. Losses prevented by use of seat belts in 1971 therefore amounted to $\$ 0.528$ billion (II percent of $\$ 4.8$ billion). When losses prevented are added to actual losses, the result, $\$ 5.3$ billion (rounded), represents total direct personal injury losses that use of seat belts could have affected in 1971 ( $\$ 4.8$ billion $+\$ 0.528$ billion).

It is then necessary to determine what portion of this loss could have been affected by use of available seat belts. Insofar as the ratio of fatalities between belt-available and nonbelt-available accident victims varies from the ratio for loss in general, this calculation undervalues the losses due to nonuse of available seat belts. Furthermore, for simplicity the calculation assumes a uniform distribution of injuries between occupant seat positions for which belts are and are not available. This results in an underestimation of preventable losses, because front seat positions are more frequently occupied, and in older cars these are the only positions for which belts are available. Total passenger car fatalities were 34,230 in 1971. NATIONAL SAFETY Councir, supra, at 56. Seat belts were available for 90 percent of all passenger car seats. Id. at 53. Insofar as current federal seat belt installation requirements are an accurate indication, the number of belts available to occupants of other types of vehicles-notably trucks and buses-is small, and is assumed to be insignificant. Use of available seat belts therefore could have affected 30,807 fatalities (90 percent of 34,230 ). The number of fatalities among belt-available occupants divided by the total number of motor vehicle fatalities for $1971,54,700$, id. at 40 , yields 56 percent. The total direct personal injury loss that use of seat belts could have affected in 1971 amounts to $\$ 5.3$ billion. Therefore, the minimum estimate of total direct reducible losses attributable to accident victims to whom seat belts were available during 1971 is $\$ 3.0$ billion (56 percent of $\$ 5.3$ billion). Since the loss-preventive potential of seat belts is 33 percent, Huelke, supra note 27, at 203, the minimum estimate of direct losses due to nonuse of available seat belts during 1971 is $\$ 1.0$ billion (33 percent of $\$ 3.0$ billion).

29 The additional pain and suffering resulting from nonuse of available seat belts is a cost because it is something someone would prefer to avoid or would demand payment to endure.

30 Indirect losses to employers, consumers, and investors are additional costs of production caused by the absence of accident victims from work. Franklin, Chanin, \& Mark, $A c$ cidents, Money, and the Law: A Study of the Economic Facts of Personal Injury Litigation, 61 Colum. L. REv. 1, 2 n.5 (1961). Automobile accident victims may also incur substantial publicly financed vocational rehabilitation expenses that are not included in medical cost computations and are not outweighed by resultant increases in productivity. See generally Statement of Dr. Philip Lee, Hearings on S. 3005 Before the Senate Comm. on Commerce, 89th Cong., 2d Sess., ser. 89-49, 105-06 (1966).

31 The cost of an activity is its marginal cost, that is, the cost that would be avoided if the activity were suspended. See Coase, supra note 12, at 131-33. Thus, the marginal cost of nonuse of seat belts includes all the costs that would be avoided if belts were used. Professor Linden has argued, however, that part of the total cost of nonuse of seat belts should be considered a cost of the negligent defendant's activity. Linden, Torts-Seat Belts and Contributory Negligence, 49 CAN. B. REv. 475, 480-81 (1971). He offers the hypothetical case of a plaintiff who sustains bruises assessed at $\$ 1,000$ and a broken leg assessed at $\$ 2,000$, only the latter injury being attributable solely to nonuse of a seat belt. Linden suggests that the defendant must pay, in addition to the total cost of the bruises, a portion of the cost of the broken leg, based on a comparative allocation of fault. Since very little is 
then becomes whether this segment of accident costs can be more efficiently avoided by drivers through accident-preventive precautions or by the larger class of all automobile occupants through use of seat belts, or whether, perhaps, neither group can cost-justifiably prevent the harms due to nonuse.

\section{B. Cost of Use}

The cost of using an available seat belt includes four components: ${ }^{32}$ risk assessment, attentiveness, tactile inconvenience and physical effort, and aesthetic loss. Risk assessment costs are incurred by each potential user in ascertaining whether driving creates a substantial risk of personal injury that could be significantly reduced by using a seat belt. The long-standing tort law policy that one is not responsible for "unforeseeable" harms is based on a desire to avoid imposition of excessive risk assessment costs. These costs must be evaluated in the context of extensive safety campaigns about automobile accidents and the safety value of the device, because this dissemination of information clearly reduces the risk assessment costs that potential seat belt users incur. ${ }^{33}$ Attentiveness costs are created by attempts to remind the user to employ the seat belt and to make the use routine. Since seat belt warning devices are now required by federal regulation, ${ }^{34}$ this cost is lower for occupants of late model cars. The costs of tactile inconvenience and actual physical effort are, respectively, the value of whatever discomfort may be caused by wearing seat belts and the energy expended in buckling them. Aesthetic loss is a residual category of undefinable unpleasantness that some automobile occupants apparently associate with the use of seat belts. ${ }^{35}$

These four components of the cost of using an available seat belt are not easily measurable because there is no market for the services they represent. Transaction costs are too high for potential seat belt users and potentially negligent drivers to negotiate a price for these services. Current widespread nonuse, however, indicates that the cost of use is

known about the marginal cost of drivers' precautions, the question what recovery should be allowed in cases of seat belt nonuse is not free from ambiguity. But a splitting of losses according to an intuitive sense of fault divorced from costs is not likely to be correct. See text and notes at 41-44 infra.

32 The cost of the belt itself is excluded since by hypothesis the device is "available." See note 25 supra.

33 Promulgation of a new liability rule might be expected to reduce this cost even further, by confronting potential users with the costs of nonuse. See text and notes at note 46 infra.

3449 C.F.R. $\$ 571.208$ (1972).

36 See G. Blomgren \& T. Scheuneman, Psychologrcal Resistance To Seat Belts (Northwestern University Traffic Institute 1961). 
greater than that portion of the cost of nonuse that the existing liability rule is perceived to impose on nonusers. The currently uncompensated cost of nonuse includes: (1) losses from accidents caused by a nonuserdriver; (2) losses from accidents in which neither party is negligent; (3) losses for which another party is liable but unable to pay; and (4) losses for which the compensation scheme does not permit recovery, such as attorneys' fees, to the extent that the jury does not make an allowance. Although the cost of use is larger than the perceived sum of these four items, which are paid directly by nonusers, the cost of use may well be less than the total cost of all injuries that such use could prevent.

For regular use of seat belts under the present liability rule, it would be necessary for automobile drivers and passengers to agree among themselves that use of seat belts is less costly than nonuse, so that each could rely on use of the device by all others. Without this agreement there is no deterrent to "free riders"- those drivers who reap the benefits of seat belt use by all others but do not use belts themselves. Since the transaction costs of an agreement are prohibitive, ${ }^{36}$ it must be determined whether the drivers and passengers would arrange for regular belt use if the transaction were possible. Although lack of knowledge as to the cost of seat belt use renders a direct weighing of costs unfeasible, a presumption that will lead to greater efficiency can be formulated. The cost to automobile occupants of prevention by use of seat belts is probably less than the cost of the harms themselves. If this is true, then a rule of liability for nonuse would yield a cost reduction just as if an efficiency-increasing transaction had occurred. But even if the cost of seat belt use exceeds the cost of the harms, there will be no decrease in efficiency. ${ }^{37}$ The only result of changing the rule of liability would be to shift the obligation to pay from all

36 The cost of arranging the hypothetical transaction would be even greater than described, because the indirect losses from nonuse of seat belts fall on many groups-in some cases on the entire population.

37 This would not be true if the costs of administering the new liability rule exceeded those of administering the old one by more than the gain in efficiency yielded by the change; but that is unlikely. Although the new liability rule would increase expert witness fee costs and lengthen trials slightly, the frequency of settlements may also increase, since in many cases the reduction in the expected value of a plaintiff's claim would make litigation unattractive. If, for example, plaintiff had reason to believe that 90 percent of his loss resulted from nonuse of a seat belt, the cost of litigation might be greater than the remaining 10 percent of his loss discounted by the probability of winning. The marginal cost of increased witness fees and trial durations is probably small compared with the initial cost of going to trial, and therefore even a modest increase in the frequency of settlements would absorb a large number of increases in witness fees and trial durations. $C f$. note 53 infra. 
automobile occupants to drivers, ${ }^{38}$ and this redistribution would be blunted by the significant overlap between the two groups. Since income effects should be set aside in determining the appropriate liability rule, ${ }^{39}$ whatever minor redistributions might occur ${ }^{40}$ would be as inconsequential as the reverse redistributions effected by the present rule.

\section{The Cost of Accident Prevention by Drivers}

Although many accident-preventive precautions are available, drivers can do little, as drivers, to mitigate resulting injuries. ${ }^{41}$ Viewed in isolation, therefore, the segment of automobile accident costs attributable to nonuse of seat belts cannot be prevented by drivers alone. But since the losses that can be eliminated by seat belt use are part of the total accident costs facing drivers, shifting part of that cost to all automobile occupants might cause a reduction in accident-preventive precautions. This substitution of the injury-preventive precaution of using seat belts for some measure of accident-preventive precautions is not a disadvantage if use of seat belts reduces accident costs more efficiently. Consequently, an obligation to use available seat belts would be inappropriate only if, first, this self-protective precaution reduces the expected cost of preventable accidents for drivers to an amount less than their investment in preventing those accidents, and, second, this self-protective precaution is less efficient than the accident-preventive precautions currently taken by drivers. ${ }^{42}$

38 Even if regular use of seat belts by all passengers and drivers were not cost-justifiable, imposing the obligation to use the device is wise because it will induce drivers to adjust their precautionary behavior more precisely to their expected accident costs. Drivers would adopt whatever mixture of accident-preventive and injury-preventive precautions would minimize their costs, and that mixture would vary among drivers. The present liability rule provides no incentive to make this adjustment.

39 See text and notes at note 17 supra. These redistributions might, for example, benefit nondriver injurers, such as railroads, or recidivist accident-causing drivers, see note 47 , para. 2 infra, at the expense of the broader class of drivers who do not use seat belts.

40 If income effects were considered, changing the present liability rule would still be desirable for the sake of equity insurance pricing. Insureds who do not use seat belts cause higher insurance costs than those who do. These higher costs are not borne solely by negligent drivers, but by all drivers in the same liability insurance pool with negligent drivers. Thus, part of the insurance bill paid by the driver who regularly uses his seat belt and never causes an accident represents the costs resulting from nonuse of seat belts. By shifting these costs into accident insurance pools, liability for nonuse would reveal who are the high-cost accident insureds. See D. Brainard, Price VariablutTy in the AUtomobile INsurANCE MARKET 55-57 (1970) (U.S. Dep't of Transportation).

41 Drivers could drive more slowly, which, in addition to lessening the frequency of collisions, might reduce the severity of resulting injuries. But there would still be an increment of injury preventable only by use of seat belts and other purely self-protective devices.

42 The second condition exists when: (a) the accident cost preventable by the self-pro- 
The possibility that liability for nonuse of seat belts will unjustifiably reduce driver incentives to prevent accidents is greater if, for some reason such as preference for risk, drivers are not presently takıng all cost-justifiable precautions. There is, however, reason to suspect that this is not the case. In recent years, accident costs per vehicle mile have remained fairly stable, ${ }^{43}$ with no significant modification in the precautionary obligations imposed on drivers. ${ }^{44}$ Drivers have, therefore, had sufficient time to assess the costs of precautions and are taking those that are warranted. If further precautions were cost-justified, drivers would be taking them in order to reduce their liability for accident costs.

\section{Deterrent Effect of Liability Rules}

Some commentators have argued that liability rules have no effect on accident prevention. ${ }^{45}$ In terms of cost analysis this assertion means either that the standard of care is too stringent, and therefore prevention of many traffic accidents is not cost-justifiable, or that drivers are unaware of the costs of various types of negligent behavior and have no cost-justifiable way of ascertaining them. Criticism of failure to meet a negligence standard that is too strict is merely a complaint against the value placed on what the law has deemed negligent conduct. It is a criticism of taste, about which little can be said in economic terms.

The problem of unawareness of risks has been mitigated by publicly and charitably financed safety campaigns. But driver ignorance about

tective precaution, minus (b) the cost of the self-protective precaution, is less than (c) the accident cost prevented by precautions invested in by initial injurers, minus (d) the cost of the precautions invested in by initial injurers.

It is plausible that the first condition exists in the seat belt case, but highly implausible that the second condition exists. It was estimated earlier that regular use of available seat belts would have reduced direct personal injury costs by $\$ 1$ billion. Presumably such use would reduce nonestimable indirect costs by a similar percentage, see text and note at note 28. If that estimate is correct, regular use of seat belts also would reduce by similar proportions, with no additional cost, the losses in any accidents resulting from a reduction in driver precautions. The shift of losses caused by nonuse of seat belts from initial injurers to seat belt nonusers would be blunted significantly by the overlap between the two groups, further reducing the likelihood of any disincentive effect on drivers. Moreover, the property damage costs facing drivers would be unaffected. See text and notes at note 49 infra.

43 National Safety Councre, supra note 28, at 40.

44 Nonvolitional obligations to purchase safety equipment are not relevant and are therefore excluded.

45 Compare O'Connell, Taming the Automobile, 58 Nw. U.L. REv. 299, 312-13 (1963) and D. Kiein \& J. Wailer, Causation, Culpability, and Deterrence in Highway Crashes 136, 137, 141 (1970) (U.S. Dep't of Transportation) with Lawton, Psychological Aspects of the Fault System as Compared With the No-Fault System of Automobile Insurance, 20 KAN. L. REv. 57, 58-64 (1971). 
seat belt use may persist. Although many drivers would pay for information about accident costs and risks, the developers of this information would have no way to confine it to paying customers. ${ }^{40}$ Liability for nonuse of seat belts would more accurately associate activities with their costs, since the costs of alternative courses of action would be reflected in accident insurance rates. ${ }^{47}$

To sustain his case, the critic of deterrence theory must show that all drivers either value the costs of seat belt use more highly than the costs such use can prevent, or are too uninformed or unintelligent to appreciate the costs involved. If, as seems likely, any drivers or passengers are deterred from causing injuries preventable by use of seat belts, changing the present liability rule would increase economic efficiency.

\section{The Proposed Rule of Liability for Nonuse of Seat Belts}

\section{A. The Proposed Rule}

The change in the present liability rule could proceed either by application of the doctrine of contributory negligence in order to deny recovery completely in instances of nonuse of available seat

46 Posner, Reflections on Consumerism, U. CHI. L. School REc., Spring, 1973, at -.

47 Although there is no theoretical difference between a 1 percent possibility of a $\$ 10,000$ loss and the 100 percent certainty of a $\$ 100$ insurance premium, the concrete cost of an insurance premium increases the availability to potential seat belt users of information about expected accident costs. It is likely, moreover, that accident insurance rates are more accurate representations of cost than liability insurance rates because high-cost insureds are subsidized by other insureds. There are no such subsidized "assigned risk" pools for accident insurance.

If the rate of recidivism for automobile accidents were low, increased insurance costs might have little deterrent effect since the sanction cannot be applied until after a driver has his first accident while not using his seat belt. But recidivism for automobile accidents is high. U.S. DeP'T of Transportation, Drver Behavior and Accident Involvement: IMPLICATIONS FOR TORT LIABILITY $37-41$ (1970). In addition, it is unlikely that insurers would depend solely on premium increases to deter nonuse of seat belts. Changing the liability rule would induce insurers to warn insureds of the effect of nonuse on their premium rates and to persuade them to shift part of their insurance coverage from liability to accident policies.

The usefulness of insurance as an instrument of deterrence for the 78 percent of carowning families who carry automobile medical coverage, U.S. DEP'T OF TRANSPORTATION, Public AtTitudes Toward Auto INSURANCE 95-98 (1970), rests, of course, on the assumption that premiums are affected by accident behavior. Although that assumption may be subject to criticism in its application to insurance generally, see, e.g., O'Connell, supra note 45 , at 312-13, there are indications that insurers consider seat belt use in setting certain premium rates even under the existing liability rule. Some insurers offer higher medical payment limits to claimants who were wearing seat belts at the time of their accidents, Campbell, Seat Belt Defense Sustained, 4 Trual 56, 57 (June-July 1968). Notations concerning seat belt use appear on insurance company accident forms with increasing frequency. Levine, Legal Problems Arising from Failure to Wear Seat Belts, AM. Trial LAwyers Ass'n 20th ANnual Convention ProceEdings, \& 8.2, at 520 (1966). 
belts, or by apportionment of losses according to causation. Holding nonusers contributorily negligent would, however, be inappropriate at present because nonusers would be held responsible for accident costs that seat belt use cannot prevent. Under the loss apportionment concept, on the other hand, the seat belt nonuser's recovery would be reduced by the cost of whatever injuries seat belt use would have prevented. Drivers might, however, be held responsible under a loss apportionment rule for harms they cannot cost-justifiably prevent since it is likely that drivers are presently taking all cost-justified accident-preventive precautions. ${ }^{48}$ But this likelihood cannot be confirmed, due to lack of data on driver investment in accident prevention. Thus, although loss apportionment would cause higher litigation costs than would complete denial of recovery, ${ }^{49}$ it is a prudent first step because it minimizes the danger of adverse incentive effects on driver behavior. After the effects on accident costs of a loss apportionment rule can be measured, the possibility of complete denial can be reconsidered.

\section{B. Implementation}

A liability rule apportioning losses according to causation can be implemented through legislation or judicial decision. Changing the present liability rule by legislation is preferable because it would avoid the confinements of case precedents. ${ }^{50}$ To date, however, no legislative

48 If this hypothesis about driver investment in precautions is correct, drivers are held liable to an even greater extent under the present rule for harms they cannot cost-justifiably prevent.

49 See note 37 supra.

50 In five states, however, a statutory change would entail the repeal of laws expressly providing that nonuse of seat belts is not to affect tort recovery, IOWA CODE ANN. § 321.445 (1966); ME. Rev. Stat. AnN. tit. 29 § 1368A (Supp. 1972); Minn. Stat. ANN. § 169.685(2) (Supp. 1973); TENN. Code ANN. \& 59-930 (1968); VA. CODE ANN. \$ 46.1-309.1 (1972). Present federal law on highway safety could create important incentives for enacting a statute reducing recovery for nonuse of seat belts. The Highway Safety Act of 1966 penalizes states not implementing approved highway safety programs by withdrawal of traffic safety research grants and 10 percent of highway construction funds. 23 U.S.C. $\S 402$ (1970). THE National Uniform Standards for Highway Safety Programs, H.R. Doc. No. 138, 90th Cong., 1st Sess. (1967), specifies that the states require use of approved safety helmets by motorcyclists, 23 C.F.R. $\$ 204.4$ (1972). Motorcycle helmets, like seat belts, prevent injury after initial impact. If the standards required reduction of tort recovery where plaintiff had not used an available seat belt, the states would have a strong incentive to abandon the present economically inefficient liability rule. The Department of Transportation is considering such a requirement, $37 \mathrm{Fed}$. Reg. 15602 (1972) (notice of proposed rule making), and has enlisted the aid of Congress in encouraging the states to enact larws penalizing seat belt nonuse. "[T]he House Public Works Committee has included a provision relating to safety belt usage laws in the highway safety portion of its 1973 Federal-aid Highway Bill (H.R. 6288). In doing so, however, the Committee added an authorization for incentive payments to States that enact such laws." Letter from Lawrence R. Schneider, Chief Counsel for the National Highway Traffic Safety Administration to The University of Chicago Law Review, Apr. 19, 1973, on file at The University of Chicago Law Review. 
action has been taken. ${ }^{51}$ If the legislative silence continues, the courts should modify the present liability rule as a matter of common law.

1. By Legislation. In order to encourage the use of seat belts, a statute providing for apportionment of losses resulting from automobile accidents should create a presumption of failure to mitigate damages in those instances in which a seat belt was not used. ${ }^{52}$ In addition, because the fact of seat belt use is more likely within the knowledge of the plaintiff than the defendant, and because nonuse of seat belts is the ordinary rather than the exceptional occurrence, the burden of proof is more efficiently assigned to the plaintiff even when use is alleged. Thus, if the defendant raised the issue of nonuse, the plaintiff would recover for injuries he proves to be unrelated to nonuse of an available seat belt. If the plaintiff offered proof of his use of the belt, with no rebuttal by the defendant, the plaintiff would recover for all his injuries. This arrangement of the burden of proof conforms to traditional rules of evidence and would minimize trial costs..53

Because a significant part of accident costs comprises indirect losses falling on employers, investors, and consumers, who are not represented in tort litigation, a civil penalty must also be assessed in order to confront seat belt nonusers with the full cost of their activity. ${ }^{54}$ Although it is difficult to determine how much of the deterrent effect is due to the social opprobrium of the sanction and how much is due

51 Although no state or federal statute imposes liability for nonuse of an available seat belt, thirty-three states have statutes requiring installation of seat belts. Thirty of these are listed in Comment, supra note 27, at 142. The following must be added: MAss. ANN. Laws ch. 90 § 32G (1967); Nevada Rev. Stat. \& 484.641 (1971); Texas Civil Stat. art. 6701d $\S 139 E$ (1972). These laws have been superseded by federal regulations authorized by the National Traffic and Motor Vehicle Safety Act of 1966, 15 U.S.C. \$§ 1381-1431 (1966). Section 1392 authorizes the Secretary of Transportation to require and set standards for safety devices on motor vehicles. The states must adopt standards identical to the federal ones, except that federal, state, and municipal vehicles may be required to meet more stringent standards. Installation of seat belts in new passenger cars was required first under these regulations in 1968, 23 G.F.R. \$ 255.21 (1968) (Standard 208).

52 Exceptions would be made for such circumstances as pregnancy or abdominal surgery.

53 If use of seat belts became widespread, it would be desirable to shift the burden of going forward onto the defendant. It is possible, though unlikely, that reducing recovery for nonuse of seat belts would increase litigation costs, see note 37 supra. The problem could be remedied by a statutory formula for reduction of recovery similar to a liquidated damages clause. If, for example, it were determined that aggregate personal injury losses would be reduced by 30 percent through use of available seat belts, the statute would prescribe that nonusers could recover only 70 percent of their total olss. The effect on the behavior of the parties to automobile accidents would be approximately the same as if the amount of reduction were determined individually.

54 The problem of indirect costs limits the deterrent effect of liability rules generally. It is significant, therefore, that many accident-causative acts, such as failure to yield the right of way, subject the negligent party to a fine in addition to tort liability. This is the only practical way to confront the party with the indirect costs of his activity. 
to the threat of economic loss, experience with statutes requiring use of seat belts supports the hypothesis that civil penalties can affect behavior. ${ }^{55}$ The size of such a penalty is a matter for legislative decision $^{56}$ because the legislature is presumably best able to express the valuation of indirect losses by those who suffer them and to react to changes in the components of this calculation.

2. By Judicial Decision. The present liability rule can be modified by judicial decisions that apply to automobile accidents the same loss apportionment principle and evidentiary presumptions as the statutory proposal. ${ }^{57}$ While common law liability under such a scheme could not impose civil penalties for the indirect costs of nonuse of seat belts, the nonuser would be confronted with the full direct costs of his nonuse, and liability would be imposed on the party most able to prevent injury. ${ }^{58}$

Forty-nine reported accident cases in the United States and Canada have dealt with the seat belt issue, but only three cases have reduced the plaintiff's recovery because of nonuse. ${ }^{59}$ Although the basis of

55 New Zealand and the Australian state of Victoria have enacted statutes requiring use of seat belts. E.g., Victoria (Australia) Motor Car Act, 1958, No. 6325, reprinted to No. 7777, as amended by Motor Car (Safety) Act, 1970, no. 8074, S.31B.(1) (\$20 penalty for nonuse). The Royal Society for the Prevention of Accidents reports that the New Zealand statute "has proved enforceable, is generally accepted by the public, and most important of all, has proved extremely effective in reducing road casualties." CARE ON THE ROAD 1, 2, Aug., 1972. "The New Zealand Ministry of Transport reports a 95 percent compliance with the new regulations ...." Id., July, 1972. A similar statute is under consideration in the New York state legislature. National Observer, March 24, 1973, at 4, col. 5.

56 The civil penalty should be paid into general revenue, for if any of the fines collected were used for services that specifically benefit automobile drivers and passengers, seat belt nonusers would, in effect, receive a rebate on their accident costs.

A civil penaity could supplant the liability rule entirely. The amount of the fine could be set at the average cost of indirect and direct losses due to nonuse of seat belts. See note 53 supra. Alternatively, the fine could be set at well above the average cost of all losses due to nonuse of seat belts. This would eliminate the problem of reducing recovery for nonuse, because nonuse would become so costly as to disappear. But this type of fine would induce use of seat belts by people who value nonuse more highly than use and are willing to pay the full cost of their activity. This would reduce efficiency.

57 See text and notes at note 52 supra.

58 See text and notes at notes 36-44 supra. Because loss apportionment is the standard practice in comparative negligence jurisdictions, this discussion focuses on implementation in traditional contributory negligence jurisdictions, where even slight negligence by the plaintiff bars all recovery.

59 Mays v. Dealers Transit Inc., 441 F.2d 1344 (7th Cir. 1971); Bentzler v. Braun, 34 Wis. 2d 362, 149 N.W.2d 626 (1967); Yuan v. Farstad, 66 D.L.R.2d 295 (B.C. 1967). Three unreported decisions have also reached this result. Vernon v. Droeste, 85th Jud. Dist., Brazos County, Tex. (Jan. 9, 1966), discussed in 8 For the Defense 21 (1967); Busick v. Budner, Case No. 381-602, Milwaukee County, Wisc., Cir. Ct. (Dec. 1965), discussed in 7 For THE Defense 44 (1966); Stockinger v. Dunisch, Sheboygan County, Wisc., Cir. Ct. (Dec. 1965), discussed in 7 FOR THE DEFENSE 44 (1966). 
thirty-three of the decisions not to reduce recovery in instances of nonuse was either insufficient evidence ${ }^{60}$ or a ground tangential to the seat belt issue, ${ }^{61}$ thirteen cases have stricken the issue or barred all evidence concerning it. ${ }^{62}$ This latter group of decisions effectively rules that, as a matter of law, nonuse of seat belts cannot affect a plaintiff's recovery. ${ }^{63}$

60 Turner v. Pfluger, 407 F.2d 648 (7th Cir. 1969); Glover v. Daniels, 310 F. Supp. 750 (N.D. Miss. 1970); Truman v. Vargas, 275 Cal. App. 2d 976, 80 Cal. Rptr. 373 (Ct. App. 1969); Blitz v. Checker, 8 IIl. App. 3d 361, 290 N.E.2d 291 (1972); Schomer v. Madigan, 120 Ill. App. 2d 107, 255 N.E.2d 620 (1970); Kavanagh v. Butorac, 140 Ind. App. 139, 221 N.E.2d 824 (App. Ct. 1967); Myles v. Lee, 209 So. 2d 533 (La. App. 1968); Fontenot v. Fidelity \& Cas. Co., 217 So. 2d 702 (La. App. 1969); Cierpisz v. Singleton, 247 Md. 215, 230 A.2d 629 (1967); D.W. Boutwell Butane Co. v. Smith, 244 So. 2d 11 (Miss. 1971); Barry v. Coca Cola Co., 99 N.J. Super. 270, 239 A.2d 273 (1967); Bertsch v. Spears, 20 Ohio App. 2d 187, 252 N.E.2d 194 (1969); Siburg v. Johnson, 249 Ore. 556, 439 P.2d 865 (1968); Jones v. Dague, 252 S.C. 261, 166 S.E.2d 99 (1969); Tom Brown Drilling Co. v. Nieman, 418 S.W.2d 337 (Tex. Giv. App. 1967); Anders v. Sim, 11 D.L.R.3d 366 (Alta. 1970); McDonnell v. Kaiser, 68 D.L.R.2d 104 (N.S. 1968); Dame Lynch v. Grant, 1968 Que. C.S. (1966).

There are two unreported decisions in which defendants failed to introduce sufficient evidence: Rogers v. Race (Del. Super., Memorandum by Judge Christie, Feb. 17, 1967), discussed in Lipscomb v. Damiani, 226 A.2d 914 (Del. 1967); Brunt v. Mickelberg (S.C.N.S. Case No. 12468, 967), discussed in McDonnell v. Kaiser, 68 D.L.R.2d 104, 106 (N.S. 1968). Many cases expressly abjure any decision on the doctrinal issue. E.g., Siburg v. Johnson, 249 Ore. 556, 568, 439 P.2d 865, 871 (1968). Some courts seem reluctant even to entertain the question if the defendant has not introduced expert testimony. See, e.g., Jones v. Dague, 252 S.C. 261, 270-71, 166 S.E.2d 99, 103 (1969).

61 Lentz v. Schafer, 404 F.2d 516 (7th Gir. 1968); Mann v. United States, 294 F. Supp. 691 (E.D. Tenn. 1968); Noth v. Scheurer, 285 F. Supp. 81 (E.D.N.Y. 1968); Britton v. Dochring, 286 Ala. 498, 242 So. 2d 666 (1970); Uresky v. Fedora, 27 Conn. Supp. 498, 245 A.2d 393 (Super. Ct. 1968); Husted v. Refuse Removal Serv., 26 Conn. Supp. 494, 227 A.2d 433 (Super. Ct. 1967); Josel v. Rossi, 7 Ill. App. 3d 1091, 288 N.E.2d 677 (1972); Hale v. Cravens, 129 III. App. 2d 466, 263 N.E. 593 (1970); Deaver v. Hickox, 121 Ill. App. 2d 465 (1970); Mount v. McClellan, 91 Ill. Ap. 2d I, 234 N.E.2d 329 (1968); Laurence v. Westchester Fire Ins. Co., 213 So. 2d 784 (La. App. 1968); Estate of Abrams v. Woods, 64 Misc. 2d 1093, 316 N.Y.S.2d 750 (1970); Dillon v. Humphreys, 56 Misc. 2d 211, 288 N.Y.S.2d I4 (Sup. Ct. 1968); Sams v. Sams, 247 S.C. 467, 148 S.E.2d 154 (1966); Sonnier v. Ramsey, 424 S.W.2d 684 (Tex. Civ. App. 1968).

62 Woods v. Smith, 296 F. Supp. 1128 (N.D. Fla. 1969); Robinson v. Bone, 285 F. Supp. 423 (D. Oreg. 1968); Moore v. Fischer, 505 P.2d 383 (Colo. App. 1972); Clark v. State, 28 Conn. Supp. 398, 264 A.2d 366 (1970); Remington v. Arndt, 28 Conn. Supp. 289, 259 A.2d 145 (1969); Lipscomb v. Damiani, 226 A.2d 914 (Del. Sup. 1967); Brown v. Kendrick, 192 So. 2d 49 (Fla. App. 1966); Hampton v. State Highway Comm'n, 209 Kan. 565, 498 P.2d 236 (1972); Romankewiz v. Black, 16 Mich. App. 119, 167 N.W.2d 606 (1969); Miller v. Haynes, 454 S.W.2d 293 (Mo. App. 1970); Miller v. Miller, 273 N.C. 228, 160 S.E.2d 65 (1968); Roberts v. Bohn, 26 Ohio App. 2d 50, 269 N.E.2d 53 (1971); Robinson v. Lewis, 254 Ore. 52, 457 P.2d 483 (1969); Derheim v. N. Fiorito Co., 80 Wash. 2d 191, 492 P.2d 1030 (1972).

63 In many of these cases, legislative silence on liability for nonuse of seat belts is construed as opposition to a change in the present rule. See, e.g., Romankewiz v. Black, 16 Mich. App. 119, 124-25, 167 N.W.2d 606, 609 (1969). There is no compelling reason, however, to believe that the legislatures intend by their silence to preserve to themselves the authority to change automobile safety obligations. See, e.g., MacPherson v. Buick, 217 
These cases rest on two conclusions concerning traditional tort doctrine: that the common law duty to mitigate damages ${ }^{64}$ is inapplicable to seat belt use; and that the doctrine of contributory negligence is inappropriate when the plaintiff has failed to use an available seat belt. The former of these concepts, however, rather than being an obstacle, is a proper means for the implementation of a common law rule reducing recovery for nonuse of seat belts. ${ }^{65}$

The view is commonly expressed in both the cases and the literature that the duty to mitigate damages imposes an obligation to minimize injuries only after "the accident."66 Imposing preaccident obligations to prevent injury is thought to deny the plaintiff the well-established right to assume the due care of others. ${ }^{67}$ The purely chronological distinction on which this concept relies, however, is difficult to justify, ${ }^{68}$ and the courts have often ignored it. ${ }^{69}$ When the doctrine first appeared, opportunities for mitigation through prior precautions were few. ${ }^{70}$ It does not follow that the obligation ought never to include such precautions, or even that the doctrine was intended to preclude requiring them. The invocation in seat belt cases of the right to assume due care by others is also a superficial reading of precedent. This right

N.Y. 382, 111 N.E. 1050 (1916). See generally E. LEVI, AN INTRODUction to Legal REASONING 9-27 (1948).

64 E.g. Moulton v. Alamo Ambulance Serv. Inc., 414 S.W.2d 444 (Tex. 1967). The duty to mitigate damages is equivalent to the doctrine of avoidable consequences. See W. Prosser, supra note $3, \S 65$, at 422-24. Several courts have suggested that this duty is related to the obligation to prevent accidents. In Romankewiz v. Black, 16 Mich. App. 119 , 126, 167 N.W.2d 606, 610 (1969), the court reasoned that "[u]nbuckled plaintiffs do not cause accidents," that there is no "duty" to use seat belts, and that, therefore, nonuse "cannot be held a breach of the duty to avoid consequences or minimize damages." This suggests that plaintiff cannot be required to do anything to mitigate his damages that would not have prevented the accident.

65 Nonuse of seat belts can be viewed in terms of the plaintiff's assuming the risk of the harm resulting from nonuse. See W. ProssER, supra note $3, \S 68$. This characterization of the rule, however, may be inconsistent with state constitutional provisions on contributory negligence and assumption of risk. See note 76 infra.

66 E.g., Lipscomb v. Damiani, 226 A.2d 914, 917 (Del. Super. 1967); Comment, Negligence: Failure to Use Seat Belts and The Defense of Contributory Negligence: "Does the Reasonable Man Always Buckle Up?" 21 OKLA. L. REv. 88, 92 (1968).

67 Kleist, supra note 18 , at 621 .

68 The weakness of purely chronological distinctions was recognized by tort theorists six hundred years ago, when the trespass doctrine was broadened to include harms inflicted after "the force initiated by the defendant had come to rest ...." C. GREGORY \& H. KALVEN, Cases and Materials on Torts 54 (2d ed. 1969). See also W. Prosser, supra note 3, § 65, at 423 .

69 O'Keefe v. Kansas City W. Ry. Co., 87 Kan. 322, 124 P. 416 (1912); see cases cited notes 3-4 supra. See also Dziedzic v. St. John's Cleaners \& Shirt Launderers, Inc., 53 N.J. 157,249 A.2d 382 (1969).

70 Kircher, supra note 3. 
exists only "in the absence of notice or knowledge to the contrary."71 Automobile drivers are now constantly "on notice" concerning the possibility of an accident ${ }^{72}$ and should be held responsible for such knowledge. ${ }^{73}$

In the seat belt situation, a rule of loss apportionment does not conflict with the concept of contributory negligence, which prevails in most jurisdictions in the United States. Although the terminology of the rule is by no means uniform, ${ }^{74}$ the common view is that contributory negligence obtains only when the plaintiff's failure of due care causes the accident, rather than when it merely increases his injuries. ${ }^{75}$ Since failure to use a seat belt may increase damages, but cannot cause accidents, a rule apportioning losses would not be inconsistent with the traditional doctrine of contributory negligence. ${ }^{76}$

71 Roberts v. Bohn, 26 Ohio App. 2d 50, 269 N.E.2d 53 (1971).

72 This notice has traditionally been equated with some definite signal of an impending crash, but statistical information disseminated through safety campaigns currently provides an equally adequate form of notice.

73 The right to assume due care is, however, applicable to accidents that are too costly to anticipate. This right rests on the same ground as the "foreseeability" limitation on negligence. See text and notes at notes 22-24 supra.

74 Compare Woods v. Smith, 296 F. Supp. 1128, 1129 (N.D. Fla. 1969) and Clark v. State, 28 Conn. Supp. 398, 402, 264 A.2d 366, 368 (1970) with Sonnier v. Ramsey, 424, S.W.2d 684, 689 (Tex. 1968).

75 W. Prosser, supra note 3 , $\$ 65$, at 423.

76 Contra, Britton v. Doehring, 242 So. 2d 666, 675 (Ala. 1970). The court said that "[ $t]$ admit such evidence of nonuse would permit the jury to "compare the damages" which in practical effect might reach almost the same result as "comparative negligence'-a doctrine unknown to Alabama law." Loss apportionment in the seat belt context does not, however, imply adoption of comparative negligence, since it does not involve apportionment in cases where the concurrent negligence of defendant and plaintiff precipitate the initial impact. In addition, considering nonuse of seat belts as a failure to mitigate damages avoids conflict with constitutional provisions in some states that leave all questions of contributory negligence to the jury. E.g., ARIz. CoNST. art. 18, $\$ 5$ (1956).

Several other doctrinal arguments against changing the liability rule are occasionally raised. (1) Since uncontroverted statistics indicate that use of seat belts is not widespread, see note 27 supra, it is argued that an obligation to use an available seat belt exceeds the standard of care to which a "reasonable man of ordinary prudence would conform." W. Prosser, supra note $3, \S 32$, at 150-51. Inferring a standard of care from custom is unwise, however, because the very fact that the liability rule does not penalize nonuse may contribute substantially to the custom. Custom is not determinative of the standard of due care, e.g., The T.J. Hooper, 60 F.2d 737 (2d Cir. 1932). Hooper applies with special force to the seat belt situation because the nonuser, unlike the doctor sued for malpractice, W. Prosser, supra note 3, § 32, at 165, cannot claim professional expertise. (2) It has been suggested that to reduce recovery only in instances of nonuse of an available seat belt creates an invidious distinction. E.g., Robinson v. Bone, 285 F. Supp. 423, 424 (D. Ore. 1968). But the distinction is rational because the effort expended in use of an available seat belt is much smaller than the expense of arranging to have belts installed. (3) In Lipscomb v. Damiani, 226 A.2d 914, 918 (Del. Super. 1967), the court suggested that reduction of recovery for nonuse of an available seat belt would violate the rule that 


\section{Administrability}

It is, of course, insufficient that a liability rule be harmonized with existing concepts; the rule must be administrable by courts and juries. The major concern has been that problems of proof in seat belt cases would be insurmountable, thus denying the jury a sensible basis for apportionment and causing either pure speculation or awards based on ad hominem considerations. ${ }^{77}$ This objection rests on the hypothesis that traumatologists who study automobile accidents are less skilled than the experts who testify in traditional loss apportionment cases, such as those that involve a failure to seek medical treatment to mitigate damages..$^{78}$ The objection very likely underestimates the state of the art. $^{79}$ In addition, although precise apportionment of losses may not be possible in every case of nonuse, even an unsophisticated apportionment would, in all likelihood, be superior to the present flat rule allowing full recovery. ${ }^{80}$ Sheer speculation by the jury could be prevented by ordinary procedural safeguards. Clear instances of speculation could presumably be eliminated by the court's authority to direct a verdict or to remove issues from the jury.

an injurer must "take the victim as he finds him." The rule manifests an economic logic. It has usually been applied to victims with large incomes or permanent physical disabilities. See W. Prosser, supra note $3, \S 43$, at 262 . Wealthy persons could prevent the additional costs imposed by their presence on the streets by eliminating their large incomes, and the disabled, by eliminating their physical vulnerabilities; or, both could cease appearing in public. In most situations, the cost of either measure greatly exceeds the cost of additional losses occasioned by the presence of these persons in public places. In contrast, the cost of eliminating the physical vulnerability of a seat belt nonuser is probably less than the additional costs resulting from his presence on the highway. See text and notes at note 36 supra.

77 Miller v. Miller, 273 N.C. 228, 235, 160 S.E.2d 65, 71 (1968); Comment, Torts: Negligence in Failure to Use Seat Belts, 52 MinN. L. Rev. 918, 923 (1968).

78 E.g., Wingrove v. Home Land Co., 100 W. Va. 190, 196 S.E. 563 (1938). Expert testimony has not posed insurmountable problems in other types of apportionment cases, for example, apportioning injuries developed over a period of years for tolling statutes of limitations. Moreover, juries frequently apportion in ordinary negligence cases to avoid the harshness of contributory negligence. Blum \& Kalven, Public Law Perspectives on a Private Law Problem-Auto Compensation Plans, 31 U. CHr. L. REv. 641, 648-50 (1964).

79 For an indication of the amount of research on seat belt use, see note 27 supra. Furthermore, the relative frequency of automobile accidents provides a richer sample for scientific study than other types of personal injury situations in which apportionment is allowed.

80 Comment, The Seat Belt Defense: A New Approach, 38 FordhaM L. Rev. 94, 102 (1969). This would not be true if the average error in jury apportionments exceeds the average loss attributable to nonuse of seat belts. Thus, if, on the average, nonuse of seat belts occasions 30 percent of the plaintiff's loss, and the average error in jury apportionments is 31 percent, the present flat rule more accurately divides losses. But traditional apportionment in cases of mitigation of damages is indicative of the common sense preference for the jury's approximation over a flat rule. 


\section{CONCLUSION}

Discussion of liability for nonuse of seat belts underscores the need for a critical reevaluation of the traditional approach to tort law. Accident and prevention costs provide the best available indication of the direction in which the law should proceed on self-protective precautions. Failure to avoid needless injuries is as wasteful as failure to avoid needless accidents. Injuries should be prevented when prevention is less expensive than the harm itself. In order to minimize total costs, liability for each increment of harm should be assigned to the party for whom prevention of the harm is cheapest. This approach to accident litigation would reduce waste of resources by recognizing that liability rules not only settle disputes within the courtroom but affect behavior outside it as well. 